\title{
REFLECTION
}

\section{The Face of Cancer}

Jobn G. Scott, $M D, P b D^{1}$

Patrick Crommet ${ }^{2}$

'Department of Family Medicine, Robert Wood Johnson Medical School, New Brunswick, NJ

${ }^{2}$ Batesville School of Ballet, Batesville, Ark

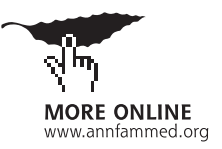

\section{CORRESPONDING AUTHOR}

John G. Scott, MD, PhD

Department of Family Medicine

Robert Wood Johnson Medical School

One Robert Wood Johnson Place

New Brunswick, NJ 08903-0019

scottjg@umdnj.edu

\begin{abstract}
Two voices tell the story of an evolving doctor-patient relationship. Seizures are the first indication of squamous cell lung cancer metastatic to the brain. Both doctor and patient describe the course of the illness, treatment, and remarkable recovery, each from his own perspective. The patient describes how the cancer became a creative as well as a destructive force, expressed in his painting and new approach to life. The essay concludes by discussing limitations of the biomedical model of disease in this case and the complex two-way nature of the healing relationship between doctor and patient.
\end{abstract}

Ann Fam Med 2003;1:52-54. DOI: 10.1370/afm.9

\section{THE DOCTOR'S STORY}

G iving patients bad news is never easy, but with Christmas 2 days away, I had to tell a patient and friend that his seizures were caused by lung cancer metastatic to his brain. I thought about Patrick's remarkable life as I walked down the hospital corridor to his room.

At age 13, Patrick received a dance scholarship with the Joffrey Ballet Company. He finished high school at 16 and moved to New York City as a Joffrey apprentice. Patrick became a solo dancer with the Royal Winnipeg Ballet, and later with the Royal Swedish Ballet in Stockholm. Eventually, tired of the rigors of the professional dancer's life, he moved back to rural Arkansas where he had lived as an infant. He taught ballet to children and helped Steve, his partner of 22 years, create and run the Northeast Arkansas Regional AIDS Network.

Entering the hospital room, I saw Patrick sitting up in bed, with Steve in a chair close by. From the devastated expression on their faces, I immediately knew that the oncologist had already delivered my news. He had informed Patrick that he had 3 months to live and told them to enjoy this Christmas because it would be their last together. Appalled by his insensitivity, but privately agreeing, I tried to repair the damage. "Take one day at a time. No one can predict when you are going to die. There is always room for hope." I could not let them go home for Christmas without some words of comfort.

In my office a few days later Patrick said, "If I have $1 \%$ of a $1 \%$ chance of beating this, I want to try." Steve, Patrick's partner, was not doing well. HIV infection, severe hypertension, heart disease and several minor strokes kept him in and out of the hospital. Patrick was determined to stay alive to care for Steve. I had concerns about the wisdom of aggressive therapy, but I arranged for Patrick to see an oncologist who would help him arrive at a treatment plan. I did not anticipate how aggressive that plan would be.

Patrick underwent a needle lung biopsy, which collapsed his lung and gave him a chest tube, but did not produce a tissue diagnosis. Brain surgery followed - again, no tissue diagnosis. A second needle lung biopsy finally made the diagnosis: squamous cell carcinoma. Another brain sur- 
gery left him with a mild expressive dysphasia and loss of fine motor control of his left (dominant) hand. Next came chest surgery with removal of the right upper lobe of his lung. A follow-up brain CT scan showed 2 new brain tumors, requiring whole-brain radiation therapy. A CT scan of the chest showed tumor in the lymph nodes. Chemotherapy failed to slow the tumor growth. Radiation therapy to the chest was the last resort.

Throughout this horrific course of treatment Patrick remained convinced that he would be cured. I was initially convinced that he was undergoing this terrible suffering for nothing. Gradually, though, Patrick's optimism infected me. I began to believe, contrary to everything I knew about his medical prognosis, that Patrick was healing. In my conversations with his other treating physicians, I got the distinct impression that we all felt we were witnessing a medical miracle. Indeed we were. Patrick is alive and well, 4 years from his diagnosis, with no evidence of cancer.

\section{THE PATIENT'S STORY}

On Thanksgiving Day, Steve and I went to his brother's house for dinner. Sitting on the couch after dinner, my lip started to tremble. My face drew up and my arm shook. It was over within a minute. Everyone thought I was having a stroke, and that made sense to me, because I have not taken the best care of myself. A CT scan showed a little black spot that the emergency room doctor thought was a broken blood vessel. Three weeks later I had a longer seizure, and this time the CT scan showed the spot had tripled in size. I had a bunch of tests, and then a doctor I didn't know walked in and announced that I had cancer of the brain and that it had metastasized. I didn't know what the heck he was talking about. I wasn't familiar with anything pertaining to cancer. He proceeded to tell me that I had approximately 2 to 3 months to live and then turned around to leave the room. He stopped at the door, turned back and said,
"I hope you two have a good Christmas; it will be your last." This knocked the whey out of me! Steve and I were in a state of shock.

I have traveled a long road from that terrible evening, and I want to share some of the things I learned about myself and about the people who cared for me.

John, as my family doctor, was a sustaining presence. His compassion meant everything to me. He seemed to know what to say to direct me, to help me see what I might do. He never once said, "Patrick, I think you are going to live," but by the same token he was willing to let me be positive about it. That was invaluable. But all medical professionals really count. One of the neatest people I remember was the nurse in the ICU after my lung surgery. She was so positive and vibrant that I couldn't allow myself to be negative around her, and that was really vital to me. I wish that every physician, for just a day, could be in the same kind of situation and be dealt with as Mr. Jones or Mrs. Smith and experience how patients like me are trying so desperately to hang on to just a tad of hope.

My spirituality and faith were so much a part of my healing. Every artist I have known has a deep, intrinsic spirituality. It may not be a religious attitude, but still a belief in an energy, a strength, a God that is omnipotent. I arrived at a point where I had to say, "Dear Lord, I beg you. I don't have control of my life. Please, please help me through this."

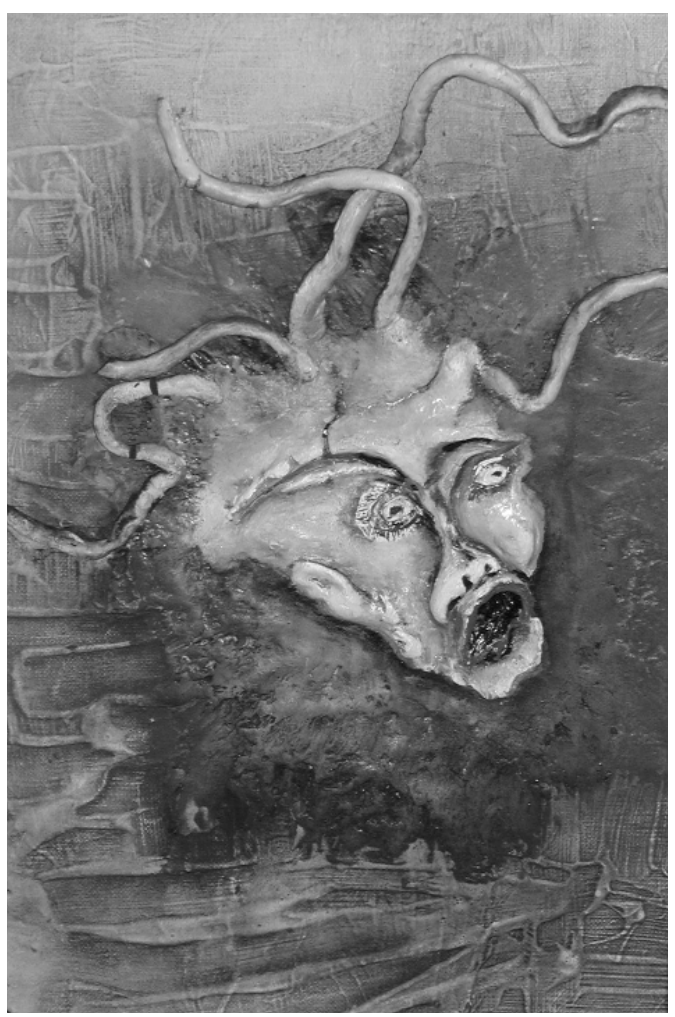

Figure. "The Face of Cancer," by Patrick Crommet. From that point on, I felt that the cancer was not going to do me in. There were things I was still supposed to accomplish.

One evening during my chemotherapy I was sitting in my living room feeling like a lump. I remembered having some of my mother's paints out in the garage. I can't explain why I wanted them; I had never painted before. Steve brought in the supplies, and I started painting. After the first day, I felt there was something emerging from the canvas that was not part of me. It was a face, a disturbing face; so disturbing in fact, that I asked Steve to take it away. I didn't want it in the house. A year later, I decided to try painting again. I went to the shed to look for a 
brush, and there was that face staring at me. I spoke to it, and said, "I'm going to take you in the house, complete you, and then burn you!" I felt so strongly that the face was my cancer. I did finish it, but I didn't burn it. [For a color reproduction of this painting and others by Patrick Crommet, follow the "supplementary data" link from the online version of this article at www.annfammed. org/cgi/content/full/1/1/52.]

That painting opened a whole new world for me. I think the radiation or surgery or both were mind altering. I began to see forms, beasts, and faces in trees and flowers. I began painting what I saw. Painting has become a great joy and a cleansing, purging tool for me. Someone commented about one of my landscapes, "I love that because I feel like I can walk into it." And I said, "I can." I can stare and see visions in clouds and trees and dawns and dusks. The colors are luminescent. Everything is brighter than it used to be. I have a whole new way of looking at everything. I look at something and see the importance of it to all of us, be it a bush or a plant or a person. I was so unaware of what a wonderful gift each day is. It can be pouring down rain, and I'm overwhelmed with joy to be alive on such a gorgeous day. These have been powerful gifts of this cancer.

The cancer has been a gift in other ways, as well. My spirituality deepened, and my relationship with my daughter strengthened tremendously. When Steve became extremely ill, I prayed that we could get him through one more time, but the cancer helped me recognize that the time had come to let go of him. He was suffering and in pain, and one night I sat on the bed, held him by the hand and said, "Steve, I know you're holding on with everything you have for me. Don't worry about me. I will be OK. If you need to, just let go." He said, "Thank you, Patrick." Two days later, he died. I think all of us have a tendency to be selfish about losing those we love. We forget that one of the greatest gifts of our lives is to be able to let go.

The cancer left me with a tremor of my left hand. I can no longer write with my left hand, nor play the piano. I have always been a terrific turner in dance. I can't turn worth a flip anymore. I have no balance. I miss the abilities that cancer has taken from me, but it has given more than taken. In retrospect, I view it as a wake-up call. I know I have been blessed, and come what may, if I dropped dead tomorrow, I have had miraculous happenings in my life, and a wonderful, wonderful life.

\section{EPILOGUE}

From the worldview of the biomedical model of disease, Patrick should be dead. To quote Patrick, "The doctors were stunned at the amount of time I had survived. In fact, a physician said, 'Patrick, we are flying by the seat of our pants. We don't understand at all why you are reacting so positively to everything we are doing."'

Patrick and I learned the limitations of that biomedical model. He could not have survived without the sophisticated medical treatment he received, but that treatment was insufficient to explain the healing that took place in his body and spirit. And in mine. Healing works in both directions. Patrick taught me to trust my intuition as well as my medical knowledge. In my relationship with him, I experienced the healing power of hope and learned to think about possibility rather than prognosis. During home visits to Patrick and Steve in the final days of Steve's life, I was powerfully affected by their love and commitment. That witness helped me reevaluate my own priorities in relationship to my family and my work.

This is more than a story about illness. It is a story about transcendence of illness, and the value of instinct and faith and trust in the relationship between a doctor and patient, and how these combined in a mysterious way to produce the healing process we found in each other.

To read commentaries or to post a response to this article, see the online version at http://www.annfammed.org/cgi/full/1/1/52.

Key words: Doctor-Patient Relationships, Cancer, Practice of Medicine/Health Care

Received January 2, 2003; accepted February 21, 2003. 